\title{
A Question of Time? A Longitudinal Analysis of the Relationship between News Media Consumption and Political Trust
}

\author{
Jesper Strömbäck', Monika Djerf-Pierre², \\ and Adam Shehata ${ }^{2}$
}

\begin{abstract}
Although there is plenty of research investigating the linkages between news media use and political distrust, virtually all of these studies focus on the impact of media use on political distrust at a particular point in time. At the same time, the transition from low-choice to high-choice media environments suggests that the relationship might not be stable across time. Whatever the linkages between news media use and political distrust were in the 1980s, 1990s, or 2000s, it cannot a priori be assumed that those linkages are the same or of equal strength today. Against this background, the purpose of this paper is to investigate the changing relationship between news media use and political trust across time. Among other things, the results show that there is a positive linkage between news media use and political trust but also that for some media, this relationship weakens across time.
\end{abstract}

\section{Keywords}

political trust, media effects, opinion dynamics, changing media environments

\section{Introduction}

Although the last decade has witnessed an increasing awareness that comparing across countries is essential if we are to avoid naïve universalism (Esser and Hanitzsch 2012),

\footnotetext{
IMid Sweden University, Sundsvall, Sweden

2University of Gothenburg, Gothenburg, Sweden

Corresponding Author:

Jesper Strömbäck, Mid Sweden University, Holmgatan 10, 85I 70 Sundsvall, Sweden.

Email: jesper.stromback@miun.se
} 
less attention has been paid to the importance of comparing across time. This holds particularly true for research on media effects or the relationship between news media consumption and various outcome variables. Although there are numerous longitudinal studies on, for example, how the media cover politics, there are only few longitudinal studies on the antecedents and effects of news media consumption (but see Liu et al. 2013; Prior 2007; Strömbäck et al. 2013).

At the same time, both media environments and media consumption patterns have changed significantly during the last decades. Advanced democracies have gone from low-choice to high-choice media environments, fundamentally altering the dynamics of news media use (Prior 2007; Weibull and Wadbring 2014; Williams and Delli Carpini 2011). Thus, it cannot be assumed that a media effect or a relationship between media consumption and an outcome variable, established at one point in time, holds equally true at another time. It has to be treated as an empirical question.

For example, although there is plenty of research investigating the linkages between news media use and political trust (Aarts et al. 2012; Avery 2009; Just et al. 1999; Moy and Pfau 2000; Shehata 2014), virtually all studies focus on the impact of media use on political trust at one point in time. Many prominent studies were also done when media environments were less fragmented than today. Whatever the linkages between news media use and political trust was in the 1980s, 1990s, or 2000s, it thus cannot be assumed that those linkages are the same or of equal strength today. Simply put, assuming homogeneous content or effects across time is untenable (Liu et al. 2013).

Against this background, the purpose of this study is to focus on the importance of time with respect to the relationship between news media use and political trust, and more specifically to investigate the changing relationship between news media use and political trust across time. Theoretically, the study will draw upon theory and research on media effects on political trust or, more broadly, the linkages between news media use and political trust and the O-M-A framework. According to this framework, media use is a function of opportunities, motivations and abilities (Luskin 1990). Empirically, the study will draw upon the representative Society, Opinion, Media -surveys (SOM) conducted annually in Sweden since 1986. This will provide us unprecedented opportunities to investigate whether or how the relationship between news media use and political trust has changed across time.

\section{The Impact of News Media on Political Trust}

The impact of the news media on political trust has been on the research agenda since the 1970s, when Robinson (1976) coined the term videomalaise and showed that dependency on TV journalism was associated with political distrust as well as political inefficacy in more general terms. The reason, according to him, was "the abnormal size and shape of the television news audience" in combination with the perceived credibility of the networks and the interpretive, negative, and anti-institutional character of television news (Robinson 1976: 426).

It was not until the 1990s, however, that research on the impact of the news media on political trust took off, following a wealth of evidence from across the world that 
trust in politicians and political institutions was falling (Dalton 1999; Klingemann 1999; Listhaug and Wiberg 1995). In the United States, for example, the share of voters saying that they trust the government in Washington to do the right thing at least most of the time plummeted from three-quarters to one-quarter between 1958 and 1994 (Orren 1997). Such falls in political trust called for explanations, and many suggested that the news media might be one of the culprits, not least since the trend toward declining political trust seemed to coincide with the rise of more independent, negative, and assertive news media (Nye and Zelikow 1997).

In the mid-1990s, Cappella and Jamieson (1997) confirmed what many believed, that the news media do contribute to political distrust or what they label political cynicism. More precisely, through a number of experiments, they established that the framing of politics as a strategic game activates political cynicism:

If any conclusion is supported by the pattern of findings, it is that strategy frames for news activate cynicism . . . The effect is not large; sometimes it is only marginally significant. But the pattern of differences is consistent. (Cappella and Jamieson 1997: 159)

Since then, several studies from different countries have shown, through panel data combined with media content data or experiments, that the framing of politics as a strategic game contributes to political distrust (de Vreese 2004; de Vreese and Semetko 2002; Schuck et al. 2013; Shehata 2014; Valentino et al. 2001). By framing politics as a strategic game, the media portray political actors as acting on their self-interest rather than on the common good. Through a process of strategic learning, those who are exposed to the framing of politics as a strategic game not only become more prone to adopt the strategy frame in their interpretations of political actors and their behavior but also become less trusting (Cappella and Jamieson 1997). As this framing of politics has become highly prevalent in political news in most countries, at least during elections (Aalberg et al. 2012; Patterson 1993; Strömbäck and Kaid 2008), this explanation has some face value.

Although research based on experiments or panel data combined with media content data has shown that the media tend to contribute to political distrust, research based on survey data has, however, shown more mixed findings or that news media use is correlated with higher political trust (Holtz-Bacha 1990; Newton 1999; Norris 2011). Norris (2000), for example, showed that across European countries, use of different news media is correlated with more trust in political institutions and actors or that there are no significant effects at all. A panel study in Britain at the time of the 1997 election also showed that political trust increased as election day drew closer, and that the movement was similar among the most and the least attentive to the news (Norris 2000). Based on this, and in contrast to the media malaise thesis, Norris (2000) developed her "virtuous circle" argument, according to which "attention to campaign communication and feelings of political trust are mutually reinforcing, producing a virtuous circle" (p. 251). Newton (1999) similarly found that use of news media is generally associated with more political trust as well as political knowledge and interest. 
Other studies based on survey data also find that there are no or only weak effects of news media exposure on political trust, particularly after controlling for political interest or education (Aarts et al. 2012; Albaek et al. 2014). Several studies have furthermore shown that the association between news media use and political trust varies across contexts, and that the conflict between the perspectives of media malaise and the virtuous circle argument is exaggerated. As suggested by Avery (2009), "Media exposure discourages political trust under some conditions but promotes trust under other conditions" (p. 424). This underscores the importance of investigating the linkage between media use and political trust across time as well as across countries.

\section{The Conditional Impact of News Media Exposure on Political Trust}

Not all media are alike, and nor are all citizens. One rather consistent finding in previous research is that the linkage between news media use and political trust varies across media. Although use of morning or broadsheet newspapers and public service broadcast news is generally associated with greater political trust, general TV viewing is often associated with less trust (Aarts et al. 2012; Avery 2009; Moy and Pfau 2000; Newton 1999; Norris 2000). While one of the reasons might be different pattern of news coverage in different media, another reason is that different groups of individuals tend to use different media. For example, one consistent finding is that education and political interest is strongly related to news media use (Aarts et al. 2012; Albaek et al. 2014; Moy and Pfau 2000; Norris 2000; Prior 2007; Strömbäck 2015; Strömbäck and Shehata 2010). To the extent that survey data show positive associations between news media use and political trust, they thus raise the question as to whether this should be interpreted as a selection or media effect. As noted by Norris (2000), when arguing for the virtuous circle hypothesis,

The argument so far has implicitly assumed that people who consume more news develop a more positive orientation towards the political system. But, equally plausible, it could be that those who are politically trusting pay more attention to news about public affairs. (p. 247)

Although cross-sectional data can never resolve the issue of causality, there are reasons to suspect that the importance of news media use vis-à-vis demographic and motivational factors for political trust has changed across time. Not least important is that the transition from low-choice to high-choice media environments has implications for how individual-level factors work (Aalberg et al. 2013; Bennett and Iyengar 2008; Ksiazek et al. 2010; Prior 2007; Strömbäck et al. 2013; Stroud 2011).

The most parsimonious framework for understanding these mechanisms is the O-M-A framework, according to which there are three factors explaining the extent to which people engage in a behavior such as, for example, following the news: opportunities, motivations, and abilities (Luskin 1990). As shown by Prior (2007), the key insight of this framework is that it highlights how changes in opportunities (a 
macro-level variable) affect the influence of motivations and abilities (individual-level variables). In a low-choice media environment, individuals' motivations and abilities are less important, simply because there are fewer choices, but as media environments transform into high-choice environments, individual motivations and abilities become more important.

Although the O-M-A framework on the individual level highlights the importance of both motivations and abilities, research on the implications of changing media environments has thus far mainly focused on the importance of motivations, largely leaving abilities aside (Aalberg et al. 2013; Prior 2007; Strömbäck et al. 2013). Following this line of research, three outcomes are likely to follow increasing opportunities in media choice. First, the importance of different antecedents of news media consumption is likely to change. Second, patterns of news media consumption and differences in news consumption between various groups are likely to change. Third, on an aggregate level, the effects of news media use or the relationship between news media use and various outcome variables are likely to change. Among other things, several scholars have argued that media effects are likely to become weaker. Bennett and Iyengar (2008) notes, for example, "As receivers exercise greater choice over both the content of messages and media sources, effects become increasingly difficult to produce or measure ..." (p. 708). Although focusing on partisan media effects, Arceneaux and Johnson (2013) similarly posit that increasing media choice will lead to a dilution of media effects.

Substantiating that increasing media choice might alter the importance of individual-level factors, in Sweden, Strömbäck et al. (2013), for example, found that political interest became a more important predictor of news media use over time. Although aggregate news media consumption did not change much, they also showed greater individual variation and how two groups grew in size: on one hand news-seekers, those who are heavy users of news media, and on the other hand news-avoiders, those who hardly use any news media at all (see also Aalberg et al. 2013; Ksiazek et al. 2010). This reflects the growing importance of individuals' motivations for their news media use. Presumably, this process could result in changes in the relationship between news media use and political trust.

\section{Changing Linkages between News Media Use and Political Trust? Research Question and Hypotheses}

In most previous theory and research, political trust is conceptualized as the dependent and media use as independent variable. Although we prefer to speak of the relationship between media use and political trust rather than media effects-as cross-sectional data can never solve the question of causality - we will thus follow this path.

Although there are several indicators of political trust and similar concepts such as political distrust and cynicism that have been used in previous research, in this study political trust will be operationalized as trust in the national parliament. The first reason is that the national parliament can be considered the most important political institution in parliamentary democracies. The second reason is that the national parliament 
is less subject to variation in political trust based on the partisan composition than, for example, trust in government (Oscarsson and Holmberg 2013). The third and more pragmatic reason is that we have data for trust in the national parliament for almost three decades (1986-2013).

Although there are many studies on the linkages between news media use and political trust, there is no longitudinal study in this area focusing on the importance of time. On the most general level, the main research question is thus as follows:

Research Question 1: How has the relationship between news media use and trust in parliament changed between 1986 and 2013 ?

Different scenarios are plausible. On one hand, increasing media choice suggests that individuals' motivations have become more important predictors of news media use (Arceneaux and Johnson 2013; Prior 2007; Strömbäck et al. 2013), while previous research as discussed above shows that political interest is correlated with news use. At the same time, those with greater political interest usually have greater trust in political institutions and actors and than those with less political interest (Holmberg 1999; Oscarsson and Holmberg 2013). One study, for example, shows that the difference between those very and not at all politically interested is 11 percentage points, a larger difference than between those with high and low education or high and low income (Norén Bretzer 2005). If it indeed is the case that political interest over time becomes a more important predictor of news media use while those who are politically interested have greater political trust, this implies a stronger and more positive relationship between news media use and political trust across time. Focusing on total news media consumption, this leads to our first hypothesis:

Hypothesis 1 (H1): The relationship between total news media consumption and trust in parliament will (a) become stronger and (b) more positive across time.

On the other hand, research also shows that the framing of politics as a strategic game tends to decrease political trust, and there is some-albeit not covering the full-time period of this study - research suggesting that that this framing has become more common across time (Aalberg et al. 2012; Asp and Bjerling 2014; Strömbäck 2013). Thus, our contrarian and second hypothesis is as follows:

Hypothesis 2 (H2): The relationship between total news media consumption and trust in parliament will (a) become stronger and (b) more negative across time.

The relationship between news media use and political trust may, however, vary across media. Avery (2009), for example, found support for the media malaise thesis with respect to the relationship between TV exposure and political trust but for the virtuous circle thesis with respect to the relationship between newspaper use and political trust. Along similar lines, Newton (1999) found a stronger relationship between reading broadsheet newspapers and political trust than between reading 
tabloids or watching TV news and political trust, while Holmberg (1999) found that exposure to public service TV and radio is associated with more trust in politicians while exposure to tabloids and commercial TV and radio is associated with less trust. At least in Sweden, one reason might be that commercial TV news and the tabloids have a consistently stronger tendency to frame politics as a strategic game and as scandals than public service TV news and the national morning newspapers (Strömbäck 2013). Swedish research also suggests stronger relationships between political interest and watching public service TV news or reading broadsheets, than between political interest and watching commercial TV news or reading tabloids (Strömbäck and Shehata 2010). Thus, previous findings pertaining both to the relationship between news media use on one hand and political trust and political interest on the other, and to the framing of politics in different media, lead us to the next set of hypotheses:

Hypothesis 3 (H3): The relationship between watching public service TV news and reading morning newspapers on one hand, and political trust on the other, will (a) become stronger and (b) more positive across time.

Hypothesis 4 (H4): The relationship between watching commercial TV news and reading tabloids on one hand, and political trust on the other, will (a) become stronger and (b) more negative across time.

Although our key interest is the importance of time with respect to the relationship between news media use and political trust, changes across time might not be linear. One finding in previous research is that election campaigns tend to mobilize people politically, leading to increasing political trust in election years (Holmberg 1999; Strömbäck and Johansson 2007). Whether that also means that the relationship between news media use and political trust will be stronger during election years compared with nonelection years is not entirely clear, but it is plausible and worth exploring. Thus, our fifth hypothesis is as follows:

Hypothesis 5 (H5): The relationship between total news media consumption and trust in parliament will be stronger during election years than during nonelection years.

On a general level, and as reflected in previous theory and research, the relationship between news media use and political trust could be the result of a media effect or a selection effect, or a combination. As in all studies relying on cross-sectional data, it is impossible to establish the direction of causality. As most previous theory and research have conceptualized the relationship as one in which media use influences political trust, this is our starting point as well. Simply put, we want to know whether the relationship between news media use and political trust—or the media effects on political trust - has changed over time. To the extent that the relationship has changed, it does of course not preclude that the reason might be stronger selection effects across time. We will return to this discussion. 


\section{Data and Methods}

To reiterate, the purpose of this study is to focus on the importance of time with respect to the relationship between news media use and political trust, and more specifically to investigate the changing relationship between news media use on political trust across time. Empirically, we will draw on the annual surveys conducted by the SOM Institute at the University of Gothenburg (Weibull et al. 2014). Starting in 1986, a random sample of the Swedish population drawn from census registers and including between three thousand and nine thousand persons aged fifteen to seventy-five years (recent surveys sixteen to eighty-five years) receive the survey. The response rate is on average 65 percent, ranging from 53 percent (2013) to 70 percent (1987; Vernersdotter 2014). The distribution of responses equals the proportion of the Swedish population with respect to gender and region, but there is a slight underrepresentation of younger people and those with an immigrant background. The data set used here consists of pooled data where all surveys over the years 1986-2013 have been combined in a single set.

Although cross-sectional surveys can never establish the chain of causality, based on previous theory and research about the relationship between media use and political trust, we will treat political trust as dependent variable and measures of media use as independent variables. We will also control for a number of other relevant variables.

\section{Dependent Variable}

The key dependent variable is "Trust in the national parliament," measured by the question, "How much trust do you have in the way the following institutions/groups do their job?" The institutions included in the questionnaire have varied over time but "Trust in parliament" has been included in the survey every year since 1986. The response alternatives range from 5 (very much) to 1 (very little). Because response alternatives were altered in 1987, this year is excluded from this study. In the analysis, we will treat the 5-point scale as an interval scale using ordinary least squares (OLS) regression analysis. To validate the results, we have also tested all models using ordinal regression, and the ordinal analyses yield essentially the same results with regard to the significance and relative magnitude of effects.

\section{Independent Variables}

The main independent variables are different measures of news media use focusing on four categories of news media: morning newspapers (in print and/or online), tabloid newspapers (in print and/or online), TV (commercial and public service), and radio (commercial and public service). With respect to TV and radio, we will focus on national news.

The only true interval scale in the survey is the variable "newspaper reading," which ranges from 0 (never/less frequently) to 7 (seven days a week). To facilitate the OLS regression analyses, we transformed the other media use measures so that they 
can be treated as interval scales. To obtain interval measures for radio news, TV news, and tabloid newspapers, we recoded the original ordinal variables so that values assigned to the categories emulate the scale used in the newspaper-reading variable. For example, the response alternatives for watching TV news were assigned the following values: never $=0$, less frequently $=1$, one to two days/week $=2$, three to four days $/$ week $=3$, five to six days $/$ week $=5$, and daily $=7$.

Newspaper reading. Respondents were asked how often they read at least one morning newspaper in print or online. The response alternatives range from 0 (less often than one day/week) to 7 (seven days/week). A separate variable measuring newspaper reading in "print only," using the same question, was also constructed.

$T V$ news. Respondents were asked how often they watch the news programs on public service TV (Rapport or Aktuellt) or on commercial TV. Commercial TV news comprises the major news shows on the commercial channels TV4 and TV3 (Nyheterna on TV4 and Update on TV3). Responses were coded as follows: $0=$ never, $1=$ less frequently, $2=$ one to two days/week, 3 = three to four days/week, $5=$ five to six days/ week, and $7=$ daily. Separate variables for watching public service TV and commercial TV news were also constructed, using the same question and coding of responses but only selecting the parts related to each form of TV news watching.

Radio news. Respondents were asked how often they listen to national news on public service radio (Eko-nyheterna) or on commercial radio. Responses were coded as follows: $0=$ never, $1=$ less frequently, $2=$ one to two days/week, $3=$ three to four days/ week, 5 = five to six days/week, and $7=$ daily.

Tabloid newspapers. Respondents were asked how often they read any of the tabloid newspapers Aftonbladet, Expressen, GT, or Kvällsposten in print or online. Responses were coded as follows: $0=$ never, $1=$ less frequently, $2=$ one to two days/week, $4=$ three to four days/week, and $6=$ six to seven days/week. Using the same question, a separate variable measuring tabloid reading in "print only" was also constructed.

Total news media use (TNMU). The main independent variable in the study is total news media use. A major challenge was to handle the pooling of twenty-eight different data sets and to construct new variables that allow for an accurate comparison of the levels of news media use over time. During the examined time period, the media environment underwent fundamental changes, such as the introduction of cable and satellite TV (1987), terrestrial commercial TV (1992), digital TV (1999), and the introduction of the Internet (mid-1990s).

The TNMU variable must measure the level of news media use in a way that is comparable across time yet takes the fundamental changes in the supply of news media platforms through online publishing and the launching of commercial radio and TV into account. To achieve this, we created the "Total news media use index" (TNMUindex). This index aims at measuring the full extent of an individual's exposure to 
news with respect to all four media categories, regardless of platform. To accomplish this, we constructed variables that measure the highest news media use score for each of the four media categories (radio, TV, morning newspapers, and tabloid papers). For example, an individual's newspaper use is measured so that it registers the highest score, no matter if the reading is online or print. An individual who reads tabloid newspapers online three days/week and a print tabloid seven days/week would thus score 7 on the tabloid reading scale and vice versa. This platform-neutral approach is the only one that allows us to include online news media consumption into the time series.

The TNMU-index was computed by summing the individual scores for all four media categories (TV news + radio news + newspapers online/print + tabloid papers online/print) for each respondent. The index varies between 0 and 27 , and the distribution of the variable is close to a normal distribution. The main advantage of the TNMUindex is that it measures the total amount of news consumption without presuming unidimensionality or a high correlation between the different varieties of news media use. Instead, the individual's pattern of news media use may vary so that some seek out all sorts of news (news-seekers) while others avoid news (news-avoiders) or choose different combinations of news media. All the news media use variables were finally rescaled to range between 0 and 1 . This allows for an easier comparison of effects between variables while keeping the variance of each variable intact. The TNMUindex was constructed by rescaling the original index to range from 0 (not using any of the four media categories) to 1 (daily use of all four media categories).

The other independent variables used in the study are election year and time. To measure the "election year" effect, we included a dummy coded variable where $0=$ not election year and 1 = election year (1988, 1991, 1994, 1998, 2002, 2006, and 2010). Finally, a variable indicating "time" was constructed with the range 0 to 27 , where $1986=0$ and $2013=27$.

\section{Control Variables}

The control variables used are interest in politics, education, gender, and age. Interest in politics is measured by the question, "How interested are you generally in politics?" The response alternatives range from 1 (not at all interested) to 4 (very interested). The variable was dummy coded so that $0=$ not interested in politics (not at all or hardly interested) and $1=$ interested in politics (rather or very interested). The level of education is derived from a question containing eight educational alternatives, which were recoded into a variable with three categories: $1=$ low (primary education), 2 = medium (more than primary education but not college or university), and $3=$ high (college or university education $)$. Respondents were also asked to indicate their gender $(0=$ male, $1=$ female) and age (sixteen to seventy-five years).

\section{Results}

We will begin the analysis by examining our dependent variable: trust in the national parliament. In the total sample, the mean trust is $3.04(S D=0.961, n=70,028)$, and 


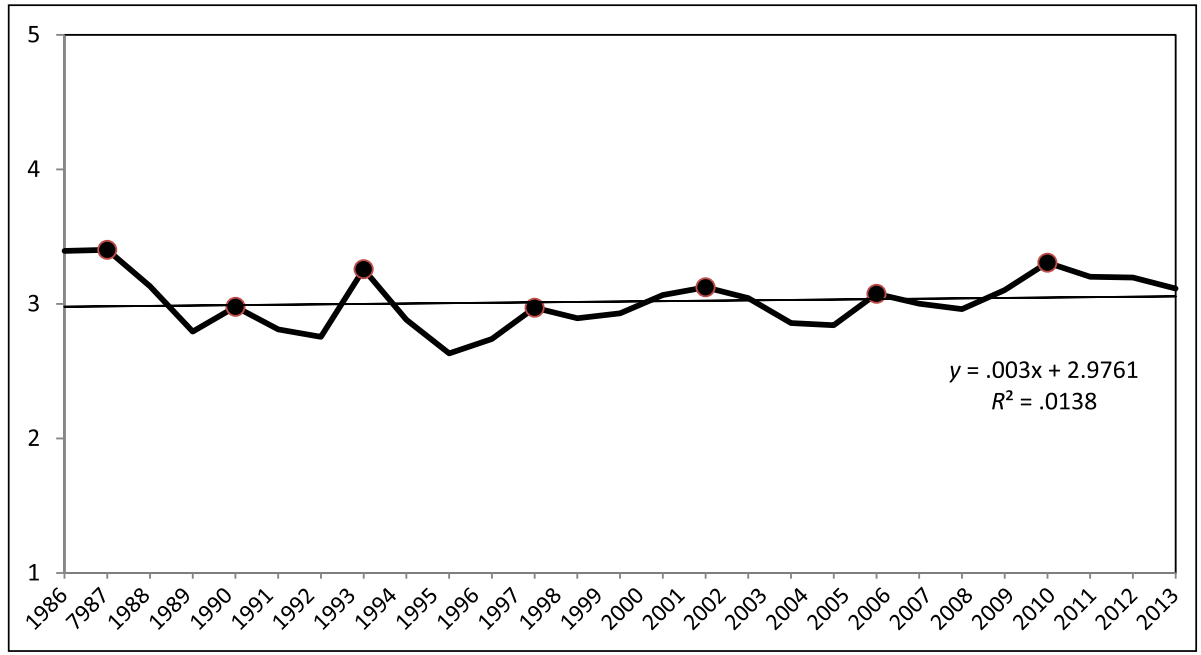

Figure I. Trust in national parliament, I986-20I3, with trend line (M).

Note. Election years are marked by a black dot. The scale is I (trust very little) to 5 (trust very much). $n$ varies between I,556 (1986) and 4,8I4 (2013) due to different sample sizes. Trust in parliament is measured by the question, "How much trust do you have in the way the following institutions/groups do their job?" The question listed a number of institutions, and "Trust in parliament" has been included in the survey every year since the start in 1986 (1987 is excluded due to different response alternatives). The response alternatives range from 5 "very much," 4 "fairly much," 3 "neither much, nor little," 2 "fairly little," and I "very little."

the response distribution is as follows: 7.6 percent "very high"; 17.2 percent "fairly high"; 42.8 percent "neither high, nor low"; 28.1 percent "fairly low"; and 4.3 percent "very low." The fact that most respondents are centered on the mid-alternative suggests that many do not have strong views on how much they trust the parliament.

Figure 1 shows changes in trust in parliament across the period 1986-2013. As can be seen, the level of trust has increased slightly over time (Pearson's $r=.052, \mathrm{p}<$ 0.001), as shown also by other studies (Holmberg and Weibull 2014; Oscarsson and Holmberg 2013). The increase is, however, small, and there are noticeable jumps in the level of trust in election years. The slight increase in the level of trust is not unique for the parliament but holds true for other political institutions as well (Holmberg and Weibull 2014).

The aim of the study is to examine how political trust is related to news media consumption. A first step of this analysis is to examine the independent variables, that is, the development of news media consumption on various platforms 1986-2013 (Figure 2). Figure 2 shows that newspaper reading has decreased over time but also that the decline in readership is reduced by the growth of online newspaper reading. A similar, but more dramatic, pattern is evident for the reading of tabloids where the increasing use of online reading has offset the decline in print readership. Sweden is thus still a country where newspaper readership is very high. TV news viewing displays a fluctuating curve, with an increase in viewing connected to the start of commercial TV in the 


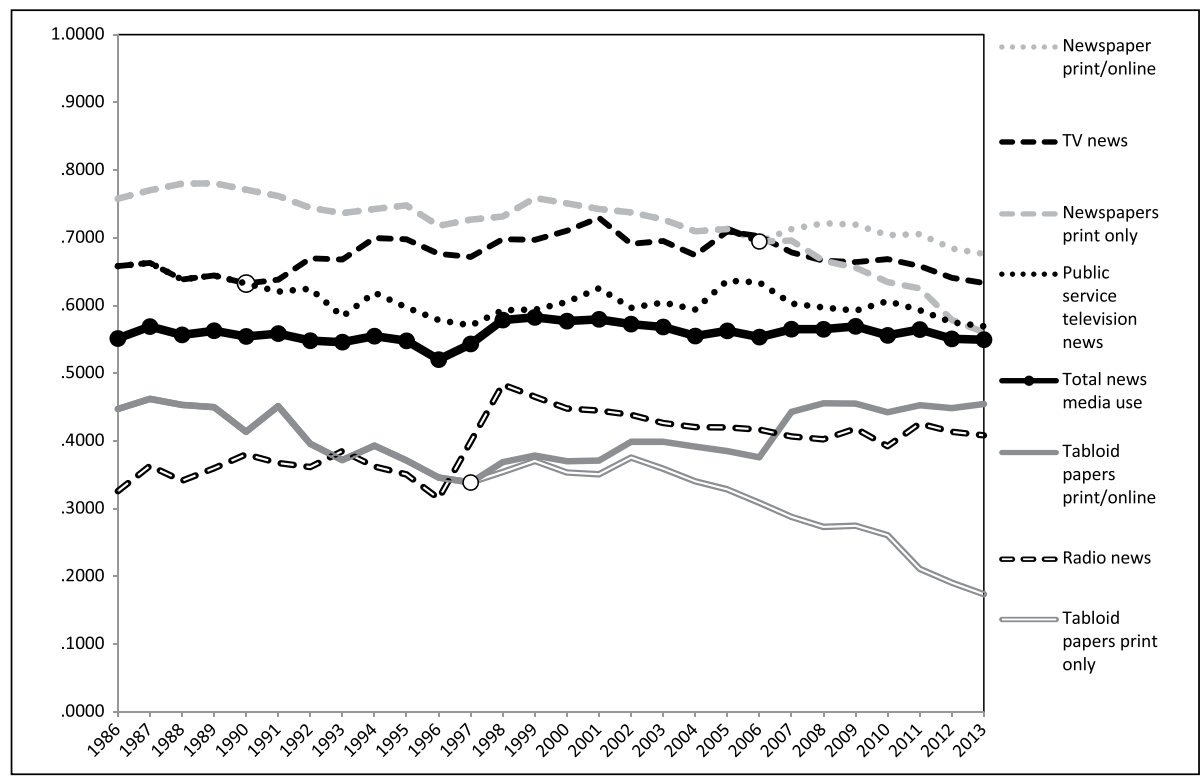

Figure 2. Longitudinal development of news media use, 1986-2013 (M).

Note. Number of responses ( $n$ ) varies between I,067 (1986) and 6,656 (2013). Newspapers print/online: Reading at least one newspaper (morning papers) in print or online, $0=$ never/less frequently, $I=$ one day/week, 2 = two days/week, $3=$ three days/week, $4=$ four days/week, $5=$ five days/week, 6 = six days/ week, and $7=$ seven days/week. TV news: Watching Rapport (public service, national), Aktuellt (public service, national), Nyheterna (commercial, TV4, national), or Update (commercial, TV3, national), $0=$ never, I = less frequently, 2 = one to two days/week, 3 = three to four days/week, 5 = five to six days/ week, and $7=$ daily. Radio news: Listening to news in public service (Ekot, national news) or news in private/commercial radio, 0 = never, $I$ = less frequently, 2 = one to two days/week, 3 = three to four days/week, 5 = five to six days/week, and 7 = daily. Tabloid papers print/online: Reading Aftonbladet/ Expressen/GT/Kvällsposten (evening tabloid papers) in print or online, $0=$ never, $\mathrm{I}=$ less frequently, $2=$ one to two days/week, $4=$ three to four days/week, and $6=$ six to seven days/week. Total news media use index (TNMU-index) $=$ (TV news + radio news + newspapers online/print + tabloid papers online/ print). All variables are rescaled to range from 0 to $I$.

early 1990s but with a decline in recent years. The line showing radio news consumption also displays an irregular pattern, with some noticeable shifts. When a question about listening to news on commercial radio was added to the survey in 1998, radio listening took a huge jump but has since then declined slowly.

When TNMU is examined by the use of the TNMU-index (the solid black graph), the mean level of the index proves to be remarkably stable across time. This means that the total news media consumption among the Swedish population has been quite resilient to the transformative changes in the media environment, although research shows that there is an increasing variation over time across individuals in their news media use (Strömbäck et al. 2013). The TNMU-index captures the extent of an individual's exposure to news with respect to all media categories. The construction of the index does thus not presume a high correlation between the usages of different media. 


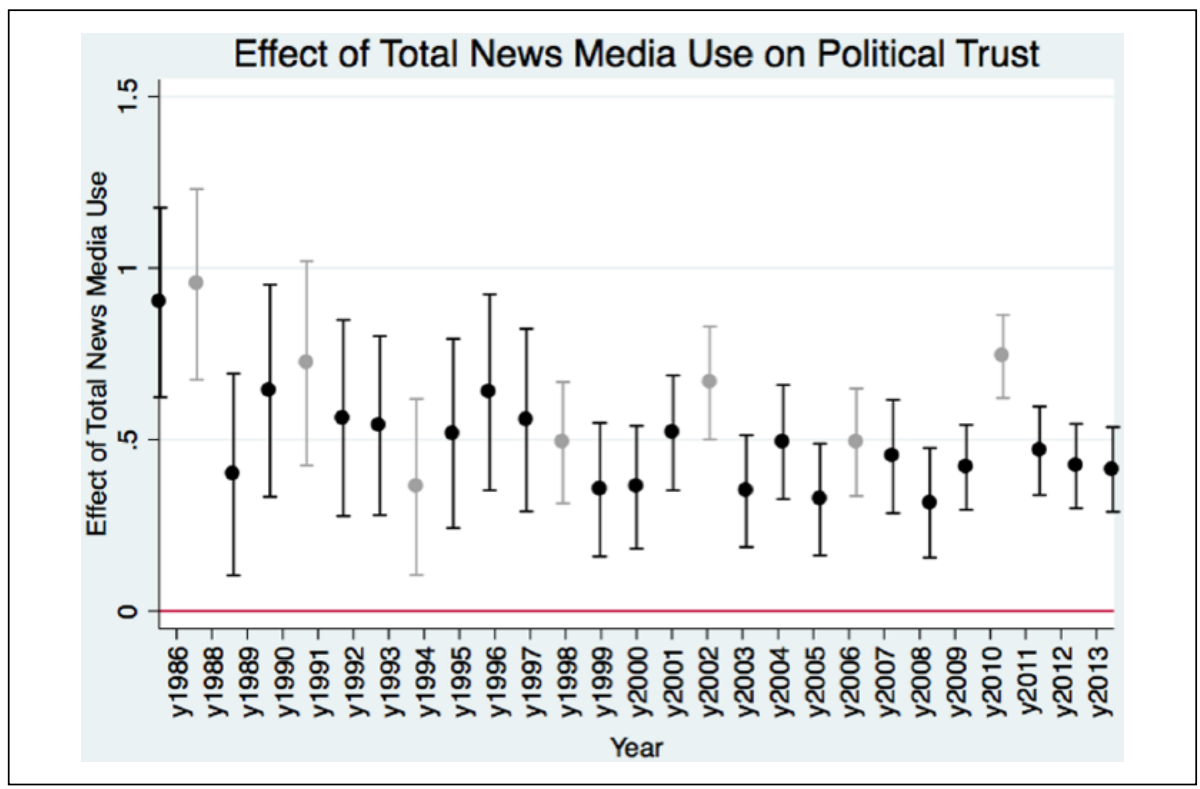

Figure 3. The bivariate effects of TNMU by year (unstandardized OLS coefficients). Note. $\mathrm{TNMU}=$ total news media use; OLS = ordinary least squares.

Instead, individuals choose different combinations of news media in their media repertoire. The stability of the TNMU over time is due to the fact that the decline in the readership of print newspapers and watching TV news largely has been compensated by an increase in online news media use.

The next step of the analysis is to examine the effect of news media use on trust in the national parliament. The TNMU-index is subsequently used as the main independent variable, but the effects of different categories of news media use will also be estimated for different news media types.

H1 predicted that the relationship between TNMU and trust in parliament would become stronger and more positive across time, even after controlling for other factors that may have an impact on political trust. $\mathrm{H} 2$, however, predicted that the relationship between news media consumption and trust in parliament would become more negative across time. As a first test of this argument, Figure 3 displays the bivariate relationship between TNMU and trust in parliament for each year between 1986 and 2013, based on twenty-seven regression models. The gray dots represent election years. Although there are some clear variations over time, with election years showing somewhat stronger overall relationships, the pattern reveals two general findings. First, the relationship between TNMU and trust is consistently positive. Second, there seems to be a trend of weakening strength of the relationship over time. Even when disregarding 1986, which appears to be an outlier year, the bivariate positive relationship seems to become smaller as time goes by. 
Table I. Effects of TNMU, Election Year, and Time on Trust in the National Parliament, 1986-2013.

\begin{tabular}{|c|c|c|c|c|c|}
\hline & \multicolumn{5}{|c|}{ Dependent: Trust in Parliament (I-5) } \\
\hline & Model Ia & Model Ib & Model Ic & Model Id & Model le \\
\hline TNMU $(0-1)$ & $.479 * * *(.033)$ & $.384 * * *(.033)$ & $.395^{* * *}(.032)$ & $.503 * * *(.073)$ & $.358^{* * * *}(.026)$ \\
\hline \multicolumn{6}{|c|}{ Gender $($ Reference $=$ male $)$} \\
\hline Female & & $.059 * * *(.009)$ & $.059 * * * *(.008)$ & $.059 * * * *(.008)$ & $.059 * * *(.008)$ \\
\hline Age (16-75) & & $-.000(.001)$ & $-.001(.001)$ & $-.001(.001)$ & $-.001(.001)$ \\
\hline \multicolumn{6}{|c|}{ Education $($ Reference $=$ medium $)$} \\
\hline Low & & $-.107^{* * * *}(.027)$ & $-.093 * * *(.018)$ & $-.094 * * *(.018)$ & $-.093 * * *(.018)$ \\
\hline High & & $.203 * * *(.016)$ & $.193^{* * * *}(.010)$ & $.193 * * *(.010)$ & $.192 * * * *(.010)$ \\
\hline \multicolumn{6}{|c|}{ Political interest (Reference $=$ not interested) } \\
\hline $\begin{array}{l}\text { Interested in } \\
\text { politics }\end{array}$ & & $.213^{* * * *}(.013)$ & $.217^{* * * *}(.013)$ & $.216 * * *(.013)$ & $.217^{* * * *}(.013)$ \\
\hline \multicolumn{6}{|c|}{ Election year (Reference $=$ not election year) } \\
\hline Election year & & $.155^{*}(.067)$ & $.166 *(.064)$ & $.166 *(.064)$ & $.08 \mathrm{I}(.05 \mathrm{I})$ \\
\hline $\begin{array}{c}\text { Time }(0-27,1986= \\
0,2013=27)\end{array}$ & & & $.006(.005)$ & $.009(.005)$ & $.006(.005)$ \\
\hline $\begin{array}{l}\text { Interaction: Time } \times \\
\text { TNMU }\end{array}$ & & & & $-.006(.004)$ & \\
\hline $\begin{array}{l}\text { Interaction: Election } \\
\text { Year } \times \text { TNMU }\end{array}$ & & & & & $.15 I^{*}(.069)$ \\
\hline Constant & $2.769 * * *(.035)$ & $2.609 * * *(.050)$ & $2.526 * * *(.102)$ & $2.466 * * *(.098)$ & $2.547 * * *(.101)$ \\
\hline$n$ & 70,028 & 70,028 & 70,028 & 70,028 & 70,028 \\
\hline$R^{2}$ & $.009 * * *$ & $.047^{* * * * *}$ & $.049 * * * *$ & $.049 * * *$ & $.049 * * *$ \\
\hline
\end{tabular}

Note. Unstandardized $b$ coefficients with year-clustered standard errors in parentheses. Highest VIF is 16 for interaction term, Time $\times$ TNMU. TNMU = total news media use; OLS = ordinary least squares; VIF = variance inflaction factor. $*_{p}<.05 . *_{p}<.01 . *_{*} *_{p}<.001$.

To examine the course of development between the two variables more comprehensively, stepwise OLS regression analyses were run. We use robust standard errors clustered by year to account for clustering in the data. Table 1 shows the results. In Model 1a, the effect of TNMU on trust in parliament is tested without any control variables. The result shows that trust in parliament is positively associated with TNMU: The higher the level of TNMU, the higher the level of trust $(b=.479, \mathrm{p}<0.001)$. The effect is still not very large. The predicted value of the level of trust for an individual who is a total news-avoider (refraining from using news media at all) is 2.769 (the intercept). An individual who is a full-fledged news-seeker (a daily user of all four categories of news media) would score 3.248 on the 5-point scale — about 17 percent higher. The adjusted $R^{2}(.009, \mathrm{p}<0.001)$ indicates that only about 1 percent of the variation in trust can be attributed to variations in the TNMU.

When election year, gender, age, education, and political interest are added to the analysis in Model 1b, the effect of TNMU decreases slightly. The addition of these variables significantly increases the adjusted $R^{2}$ of the model to $.047(\mathrm{p}<0.001$. There 
Table 2. Effects of TNMU and Election Year on Trust in the National Parliament in 1986-1995, 1996-2004, and 2005-2013.

\begin{tabular}{|c|c|c|c|}
\hline & \multicolumn{3}{|c|}{ Dependent: Trust in Parliament $(I-5)$} \\
\hline & $1986-1995$ & 1996-2004 & $2005-2013$ \\
\hline TNMU $(0-1)$ & $.475^{* * * *}(.069)$ & $.4 \mathrm{II} * * *(.050)$ & $.403 * * *(.053)$ \\
\hline \multicolumn{4}{|c|}{ Gender (Reference $=$ male $)$} \\
\hline Female & $.080 * *(.018)$ & $.044 *(.018)$ & $.052 * *(.011)$ \\
\hline Age (16-75) & $.002 *(.001)$ & $.000(.001)$ & $-.002 * *(.001)$ \\
\hline \multicolumn{4}{|c|}{ Education $($ Reference $=$ medium $)$} \\
\hline Low & $-.007(.054)$ & $-.092 * * *(.015)$ & $-.167 * * *(.024)$ \\
\hline High & $.128^{*}(.04 I)$ & $.184 * * *(.016)$ & $.216 * * *(.012)$ \\
\hline \multicolumn{4}{|c|}{ Political interest (Reference $=$ not interested) } \\
\hline Interested in politics & $.135^{* * * *}(.020)$ & $.210 * * *(.021)$ & $.244 * * *(.018)$ \\
\hline \multicolumn{4}{|c|}{ Election year (Reference $=$ not election year) } \\
\hline Election year & $.254(.146)$ & $.122(.073)$ & $.14 \mid(.090)$ \\
\hline Constant & $2.470 * * *(.104)$ & $2.513 * * *(.067)$ & $2.75 \mathrm{I} * * *(.055)$ \\
\hline n & 13,429 & 24,372 & 32,227 \\
\hline$R^{2}$ & $.035^{* * *}$ & $.041 * * *$ & $.065^{* * *}$ \\
\hline
\end{tabular}

Note. OLS, unstandardized regression coefficients, year-clustered standard errors in parentheses. Data for 1987 are missing. TNMU = total news media use; OLS = ordinary least squares.

$*_{p}<.05 .{ }^{* *} p<.01 .{ }^{* * *} p<.001$.

are clear election year effects, that is, trust in parliament increases during election years. Furthermore, higher education and political interest significantly increase trust; women display a higher level of trust than men while age does not have any effect on the level of trust. Taken together, these results show that there is a positive relationship between TNMU and trust even when education, gender, age, political interest, and election year are controlled for.

H1 stated that the relationship between news media use and trust would become stronger and more positive across time while $\mathrm{H} 2$ specified the reverse direction of the relationship. In Model 1c, "time" is added to the model. The effect of time is, however, not significant, indicating that trust does not change significantly over time. Furthermore, the interaction term between time and TNMU is not significant either (Model 1d), suggesting that the positive relationship between TNMU and political trust does not change linearly over time. These findings lend no support for either $\mathrm{H} 1$ or H2. In Table 2, we break down the effect of time by analyzing three phases: 19861995, 1996-2004, and 2005-2013. As can be seen, there is a slight decrease in effect size over time, corresponding to the weakening relationships displayed in Figure 3. But these changes are not statistically significant.

Altogether the results show that the evidence supports neither $\mathrm{H} 1$ nor $\mathrm{H} 2$. There is a positive relationship between total news consumption and trust in parliament, and it remains fairly consistent over time. 
H5 stated that the relationship between total news media consumption and trust in parliament would be stronger during election years than during nonelection years. To test this, Model 1e includes an interaction term for Election Year $\times$ TNMU. The interaction term is positive and significant, which indicates that the relationship indeed becomes stronger during election years. This election year effect can also be seen in Figure 3, where the gray dots tend to score above average compared with nonelection years.

H3 and H4 stated that the relationship between watching public service TV and reading morning newspapers on one hand and political trust on the other would become stronger and more positive across time, whereas it would become stronger and more negative across time with respect to watching commercial TV and reading tabloids. We will thus focus on the relationship between watching TV news (commercial vs. public service) and reading newspapers (morning newspapers vs. tabloids) and trust in parliament. In Table 3, we proceed to analyze the relationship between the different categories of news media use and the level of trust. As viewing of commercial TV news has only been available since the early 1990s, the results in Models 3b, 3e, and 3 f pertain to 1991-2013, whereas public service TV, morning newspapers, and tabloid papers have been measured since 1986 .

Table 3 shows that the relationship between trust in parliament and news media use indeed varies between different categories of news media. Watching news on commercial TV has no relationship (-.030) while reading morning newspapers $(.207, \mathrm{p}<$ $0.001)$ and watching public service TV news $(.231, \mathrm{p}<0.001)$ are positively associated with trust. With respect to the tabloids, reading tabloid papers has no relationship (.029) with trust. If we, however, only include reading tabloid papers in print (not shown in Table 3), there is, however, a negative relationship.

In relative terms, the positive relationships between watching news on public service TV and reading morning newspapers on one hand and political trust on the other appear to be stronger than any negative relationship with the use of other types of media. This result persists when the relationship between political trust and the use of all news media categories are tested simultaneously in Model 3e.

Finally, to test whether the relationship between political trust and each media category changes linearly over time, we tested four interaction models separately (not displayed in Table 3), each including an interaction term between time and the corresponding media use measure. The only significant interaction term found was between public service television news and time $(-.008, \mathrm{p}<0.01)$, indicating that the positive relationship between watching public service television news and political trust has weakened over time. ${ }^{1}$

Overall, the results suggest that there is a positive relationship between TNMU and trust in the national parliament but also that the positive relationship is quite stable across time. Different categories of news media use relate to trust in dissimilar ways. Watching news on public service TV and reading morning newspapers are positively related to trust, whereas the effect of commercial TV and tabloid papers is nonsignificant. Of our hypotheses, only $\mathrm{H} 5$ related to the effect of election years is fully supported by the results. Instead, our results rather substantiate Avery's (2009) suggestion that "Media exposure discourages political trust under some conditions but promotes trust under other conditions" (p. 424). 


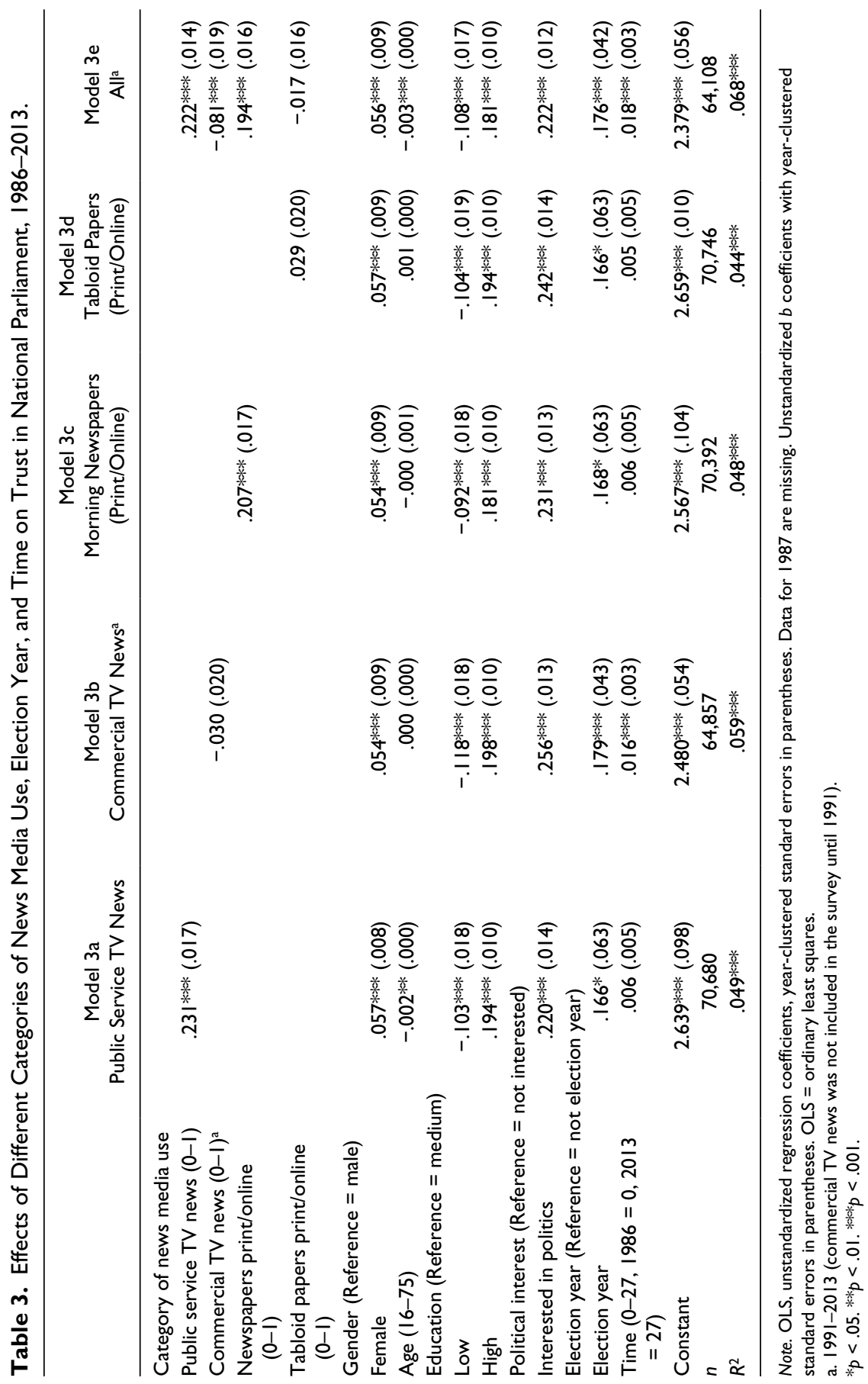




\section{Discussion and Conclusion}

Although there are several experimental and panel studies showing that the news media have or might have a negative impact on political trust (Cappella and Jamieson 1997; de Vreese 2004; Shehata 2014), survey-based studies have usually found more mixed and weaker results (Aarts et al. 2012; Albaek et al. 2014), with several studies showing a positive relationship between news media use and political trust (Newton 1999; Norris 2000, 2011). Despite such conflicting findings, the common denominator in most research is the assumption that time does not matter and that the relationship is stable across time. To our knowledge, this is the first longitudinal study of the relationship between news media use and political trust.

In line with previous survey-based research, the results show that there is a positive relationship between news media use and political trust, although the effect is quite weak. Also in line with earlier studies, the results show that the relationship varies across media. Although the relationship between news media use and political trust is positive with respect to morning newspapers and watching public service TV news, it is nonsignificant with respect to watching commercial TV news. It is more mixed with respect to the tabloids, depending on whether reading of tabloids take place offline or online.

Our key interest, though, is the importance of time. Interestingly, despite all the changes in media environments and media consumption patterns that have taken place during the more than twenty-five years covered by this study, there are no significant linear differences in the relationship between TNMU and political trust across time. The relationship becomes slightly weaker, but not significantly so. The only relationship that changes significantly across time is the relationship between political trust and watching public service TV, which over time becomes somewhat weaker.

Taken together, these results offer a complex picture with respect to the importance of time. In most of the cases, time appears not to matter that much, in the sense that the results show the same patterns over time and no significant, linear differences. In other cases, such as with respect to watching public service TV, the relationship becomes weaker across time, suggesting that time matters. In yet other cases, such as with respect to the significantly stronger relationship between news media use and political trust in election years compared with off-election years, time matters, but then it is not a matter of linear changes across time.

In essence, then, time might matter. From a broader perspective, there are at least two ways of looking at this. On one hand, our findings suggest that scholars should be careful not to a priori assume homogeneous relationships between news media consumption and various outcome variables - or media effects - across time. The strength and direction of the relationships between news media consumption and different outcome variables might vary across time, and thus there is a need for further longitudinal research related to other concepts where research at a particular time suggests a particular relationship or effect. On the other hand, and perhaps paradoxically, the findings also suggest that the basic relationship between news media use and political trust is quite constant over time in terms of its direction. Even though there are fluctuations, it is thus rather safe to conclude that the relationship between overall news media use 
and political trust in general is positive-regardless of all changes that have taken place during the last three decades.

One key question is, however, why the relationship between news media use and political trust has not changed more across time. Although this study cannot provide a definitive answer, there are several potential explanations. First, it might be the case that the relationship is quite stable, although the results pertaining to public service TV watching and the election year effects cast some doubts on such an explanation. Second, it might be the case that different forces cancel each other out. This would, for example, be the case if stronger selection effects (e.g., those who are politically interested and trusting follow the news media more closely) over time are offset by media effects (e.g., a stronger tendency to frame politics as a strategic game). Relatedly, the difference between print and online reading of the tabloids might reflect that the tabloids online have been able to attract not only a broader but also a different audience than the print tabloids. When we combine the measures, we find no significant relationships, but looking at print reading only, there is a negative relationship with political trust. Third, the results might reflect that other factors have become more important across time, thereby blunting the relationship between news media use and political trust. For example (see Table 3), both the importance of education and political interest for explaining political trust have increased over time.

Fourth, it cannot be ruled out that the increasing complexity of media environments and hence people's media use play a part. Toward the end of our time series, social media became more important as sources of information, and while our TNMU-index is comprehensive with respect to traditional news media, and most people in Sweden still rely on traditional news media for getting the news (Bergström and Oscarsson 2014; Strömbäck 2015), our media use measures do not include social media. At the same time, it is well known that self-reported media use often is problematic (see, for example, Prior 2009), and the more complex media environments and people's media use patterns become, the more difficult it becomes to capture people's media use through surveys.

To sum up, two key results of this study is that the relationship between news media use and political trust on a general level, across several decades, is positive, but also that time in some cases matters. Hence, it should not be assumed a priori that relationships between news media use and various outcome variables are consistent over time. It should rather be investigated empirically, to get a better understanding of when and under what circumstances time matters. In that context, more research is also needed to disentangle whether or to what extent changing relationships between news media use and, for example, political trust reflect changing media effects or changing selection effects. That would require panel rather than cross-sectional data, but whether we are witnessing changing media effects or selection effects is a key question to understand the mechanisms behind changing patterns between media use and various outcome variables.

\section{Declaration of Conflicting Interests}

The authors declared no potential conflicts of interest with respect to the research, authorship, and/or publication of this article. 


\section{Funding}

The authors disclosed receipt of the following financial support for the research, authorship, and/or publication of this article: This research is part of the research project "Changing Media Environments, Changing Democracies", supported by the Axel and Margaret Ax:son Johnson Foundation.

\section{Note}

1. In fact, using an ordered logit specification yielded a significant and positive interaction term between time and commercial television news as well, which would indicate that the negative effect of watching news on these channels has become weaker over time. However, the fact that this was a borderline case $(p=.047)$ not replicated in the ordinary least squares (OLS) specification made us cautious not to overinterpret this finding.

\section{References}

Aalberg, Toril, Arild Blekesaune, and Eiri Elvestad. 2013. "Media Choice and Informed Democracy: Toward Increasing News Consumption Gaps in Europe?" International Journal of Press/Politics 18 (3): 281-303.

Aalberg, Toril, Jesper Strömbäck, and Claes H. de Vreese. 2012. "The Framing of Politics as Strategy and Game: A Review of Concepts, Operationalizations and Key Findings." Journalism 13 (2): 162-78.

Aarts, Kees, Audun Fladmoe, and Jesper Strömbäck. 2012. "Media, Political Trust, and Political Knowledge: A Comparative Perspective." In How Media Inform Democracy: A Comparative Approach, ed. Toril Aalberg and James Curran, 98-118. London: Routledge.

Albaek, Erik, Arjen Van Dalen, Nael Jebril, and Claes H. de Vreese. 2014. Political Journalism in Comparative Perspective. New York: Cambridge University Press.

Arceneaux, Kevin, and Martin Johnson. 2013. Changing Minds or Changing Channels? Partisan News in an Age of Choice. Chicago: University of Chicago Press.

Asp, Kent, and Johannes Bjerling. 2014. Mediekratin. Mediernas makt i svenska val [Mediacracy. The Influence of the Media in Swedish Elections]. Stockholm: Ekerlids.

Avery, James M. 2009. "Videomalaise or Virtuous Circle? The Influence of the News Media on Political Trust." International Journal of Press/Politics 14 (4): 410-33.

Bennett, W. Lance, and Shanto Iyengar. 2008. "A New Era of Minimal Effects? The Changing Foundations of Political Communication.” Journal of Communication 58 (4): 707-31.

Bergström, Annika, and Henrik Oscarsson. 2014. "Mittfåra \& Marginal” [Mainstream and Marginal]. In Mittfåra \& Marginal [Mainstream and Marginal], ed. Annika Bergström and Henrik Oscarsson, 11-34. Göteborg: SOM-institutet

Cappella, Joseph N., and Kathleen Hall Jamieson. 1997. Spiral of Cynicism: The Press and the Public Good. New York: Oxford University Press.

Dalton, Russell J. 1999. "Political Support in Advanced Industrial Democracies." In Critical Citizens: Global Support for Democratic Governance, ed. Pippa Norris, 57-77. New York: Oxford University Press.

de Vreese, Claes H. 2004. "The Effects of Strategic News on Political Cynicism, Issue Evaluations, and Policy Support: A Two-Wave Experiment." Mass Communication and Society 7 (2): 191-214.

de Vreese, Claes H., and Holli A. Semetko. 2002. "Cynical and Engaged: Strategic Campaign Coverage, Public Opinion, and Mobilization in a Referendum." Communication Research 29 (6): 615-41. 
Esser Frank, and Thomas Hanitzsch, eds. 2012. Handbook of Comparative Communication Research. New York: Routledge.

Holmberg, Sören. 1999. "Down and Down We Go: Political Trust in Sweden." In Critical Citizens: Global Support for Democratic Governance, ed. Pippa Norris, 103-122. New York: Oxford University Press.

Holmberg, Sören, and Lennart Weibull. 2014. "Institutionsförtroende mellan berördhet och mediebevakning" [Institutional Trust, Personal Experience and Media Coverage]. In Mittfåra \& marginal [Mainstream and Marginal], ed. Annika Bergström and Henrik Oscarsson, 11-34. Göteborg: SOM-institutet.

Holtz-Bacha, Christina. 1990. "Videomalaise Revisited: Media Exposure and Political Alienation in West Germany." European Journal of Communication 5 (1): 73-85.

Just, Marion, Ann Crigler, and Tami Buhr. 1999. "Voice, Substance, and Cynicism in Presidential Campaign Media." Political Communication 16 (1): 25-44.

Klingemann, Hans-Dieter. 1999. "Mapping Political Support in the 1990s: A Global Analysis." In Critical Citizens: Global Support for Democratic Governance, ed. Pippa Norris, 31-56. New York: Oxford University Press.

Ksiazek, Thomas B., Edward C. Malthouse, and James G. Webster. 2010. "News-Seekers and Avoiders: Exploring Patterns of Total News Consumption across Media and the Relationship to Civic Participation." Journal of Broadcasting \& Electronic Media 54 (4): 551-68.

Listhaug, Ola, and Matti Wiberg. 1995. "Confidence in Political and Private Institutions." In Citizens and the State, ed. Hans-Dieter Klingemann and Dieter Fuchs, 298-322. Oxford: Oxford University Press.

Liu, Yung-I, Fei Shen, William P. Eveland Jr., and Ivan Dylko. 2013. "The Impact of News Use and News Content Characteristics on Political Knowledge and Participation." Mass Communication and Society 16 (5): 713-37.

Luskin, Robert C. 1990. "Explaining Political Sophistication." Political Behavior 12 (4): 331-61. Moy, Patricia, and Michael Pfau. 2000. With Malice toward All? The Media and Public Confidence in Democratic Institutions. Westport: Praeger.

Newton, Kenneth. 1999. “Mass Media Effects: Mobilization or Media Malaise?” British Journal of Political Science 29 (4): 577-99.

Norén Bretzer, Ylva. 2005. Att förklara politiskt förtroende [To Explain Political Trust]. Göteborg: Statsvetenskapliga institutionen, Göteborgs universitet.

Norris, Pippa. 2000. A Virtuous Circle: Political Communications in Postindustrial Societies. New York: Cambridge University Press.

Norris, Pippa. 2011. Democratic Deficit: Critical Citizens Revisited. New York: Cambridge University Press.

Nye, Joseph S., Jr., and Philip D. Zelikow. 1997. "Conclusions: Reflections, Conjectures, and Puzzles.” In Why People Don't Trust Government, ed. Joseph S. Nye Jr., Philip D. Zelikow, and David C. King, 253-281. Cambridge: Harvard University Press.

Orren, Gary. 1997. "Fall from Grace: The Public's Loss of Faith in Government." In Why People Don't Trust Government, ed. Joseph S. Nye Jr., Philip D. Zelikow, and David C. King, 77-107. Cambridge: Harvard University Press.

Oscarsson, Henrik, and Sören Holmberg. 2013. Nya svenska väljare [New Swedish Voters]. Stockholm: Norstedts juridik.

Patterson, Thomas E. 1993. Out of Order. New York: Vintage.

Prior, Markus. 2007. Post-broadcast Democracy. How Media Choice Increases Inequality in Political Involvement and Polarizes Elections. New York: Cambridge University Press. 
Prior, Markus. 2009. "The Immensely Inflated News Audience: Assessing Bias in Self-Reported News Exposure." Public Opinion Quarterly 73 (1): 130-43.

Robinson, Michael J. 1976. "Public Affairs Television and the Growth of Political Malaise: The Case of "The Selling of the Pentagon."' American Political Science Review 70 (2): 409-32.

Schuck, Andreas R. T., Hajo B. Boomgaarden, and Claes H. de Vreese. 2013. "Cynics All Around? The Impact of Election News on Political Cynicism in Comparative Perspective." Journal of Communication 63 (2): 287-311.

Shehata, Adam. 2014. "Game Frames, Issue Frames, and Mobilization: Disentangling the Effects of Frame Exposure and Motivated News Attention on Political Cynicism and Engagement." International Journal of Public Opinion Research 26 (2): 157-77.

Strömbäck, Jesper. 2013. "Den medialiserade valrörelsejournalistiken.” [The Mediatization of Election News Coverage] In Kampen om opinionen. Politisk kommunikation under svenska valrörelser [The Battle for Public Opinion. Political Communication in Swedish Election Campaigns], ed. Jesper Strömbäck and Lars Nord, 119-149. Stockholm: SNS Förlag.

Strömbäck, Jesper. 2015. Demokratin och det förändrade medielandskapet. Mot ökade kunskapsklyftor och deltagandeklyftor? [Democracy and the Changing Media Environments. Towards Increasing Knowledge Gaps and Participation Gaps?]. Stockholm: Regeringskansliet.

Strömbäck, Jesper, Monika Djerf-Pierre, and Adam Shehata. 2013. "The Dynamics of Political Interest and News Media Consumption: A Longitudinal Perspective." International Journal of Public Opinion Research 25 (4): 414-35.

Strömbäck, Jesper, and Bengt Johansson. 2007. "Electoral Cycles and the Mobilizing Effects of Elections: A Longitudinal Study of the Swedish Case." Journal of Elections, Public Opinion and Parties 17 (1): 79-99.

Strömbäck Jesper, and Lynda Lee Kaid, eds. 2008. Handbook of Election News Coverage around the World. New York: Routledge.

Strömbäck, Jesper, and Adam Shehata. 2010. "Media Malaise or a Virtuous Circle? Exploring the Causal Relationships between News Media Exposure, Political News Attention and Political Interest.” European Journal of Political Research 49 (5): 575-97.

Stroud, Natalie. 2011. Niche News: The Politics of News Choice. New York: Oxford University Press.

Valentino, Nicholas A., Matthew N. Beckmann, and Thomas A. Buhr. 2001. "A Spiral of Cynicism for Some: The Contingent Effects of Campaign News Frames on Participation and Confidence in Government." Political Communication 18 (4): 347-67.

Vernersdotter, Frida. 2014. "Den nationella SOM-undersökningen 2013" [The National SOM Survey 2013]. In Mittfåra \& Marginal [Mainstream and Marginal], ed. Annika Bergström and Henrik Oscarsson, 531-559. Göteborg: SOM-institutet.

Weibull, Lennart, Sören Holmberg, Henrik Oscarsson, Johan Martinsson, and Elias Markstedt. 2014. “Super-Riks-SOM 1986-2012, v2014.1.2.” SOM-INSTITUTET. http://www.som. gu.se.

Weibull, Lennart, and Ingela Wadbring. 2014. Massmedier [Mass media]. Stockholm: Ekerlids. Williams, Bruce A., and Michael X. Delli Carpini. 2011. After Broadcast News: Media Regimes, Democracy, and the New Information Environment. New York: Cambridge University Press.

\section{Author Biographies}

Jesper Strömbäck is professor in political communication and Ludvig Nordström professor and chair in journalism at Mid Sweden University. He is also chair of the International 
Communication Association (ICA) Political Communication Division (2014-2016). His research focuses on political communication, political news journalism, political public relations, and the role of the media in public opinion formation.

Monika Djerf-Pierre is professor in journalism, media, and communication at the University of Gothenburg. Her research focuses on journalism, political communication, media history, gender and media, and environmental communication.

Adam Shehata is assistant professor at the University of Gothenburg. His research focuses on public opinion formation and media effects. 